\title{
Assertive discourse and folk linguistics: Serbian nationalist discourse about the cyrillic script in the 21st century
}

\author{
Srđan Mladenov Jovanović ${ }^{1}$
}

Received: 17 July 2017 / Accepted: 28 May 2018 / Published online: 21 June 2018

(C) The Author(s) 2018

\begin{abstract}
Ever since the wars of the Yugoslav secession in the nineties, linguistic nationalism has proven to have been among the more relevant instances in the discursive construction of national identity and new languages, dubbed by Ranko Bugarski as 'administrative successors' of Serbo-Croatian. Even though contemporary linguistics still classifies Serbo-Croatian as one language with regional varieties (commonly dubbed 'polycentric standardized languages' in linguistics), nationalist linguists have been working tirelessly to discursively construct their own, local languages, based on national identity, script and religion. Since most scholarly production has been dealing with nationalist linguistics related to the breakup of Serbo-Croatian during and in the immediate aftermath of the wars of the Yugoslav secession, not much has been written on the current state of nationalist linguistics in Serbia in the 21st century. This article deals with the contemporary nationalist linguist discourse on the topic of the Serbian version of the polycentric standardized Serbo-Croatian language, its discursive connections to religion, nationality and the Otherizing of Croatia as the discursive Other against which a Serbian language needs to be constructed. As the article will show, this is achieved by assertive, declarative discourse.
\end{abstract}

Keywords Cyrillic script $\cdot$ Serbian $\cdot$ Croatian $\cdot$ Nationalism $\cdot$ Assertiveness $\cdot$ Folk linguistics · Discourse Analysis

Srđan Mladenov Jovanović

srdjan.jovanovic@kom.lu.se

1 Lund University Sweden, Helgonabacken 12, Absalonhuset, 22100 Lund, Sweden 


\section{Introduction and context}

In 2005, a member of the Society for the protection of the Cyrillic script, a socially and politically active organization aptly named-'The Cyrillic script' (Ćirilica, Ser-Cro.) - summed up the worries of the Society: there is 'violence over the Cyrillic script and over everything that is Serbian' (Vidić 2005). This is the summa of the contemporary debate (for lack of better words other than 'debate', having in mind that opposing views are disregarded almost in their entirety) about the state of the Cyrillic script in Serbia. In the minds of the discourse creators, the Cyrillic script-used parallel to the Latin script in the Serbian version of the polycentric, standardized Serbo-Croatian language-is being oppressed, and is thus in the process of being erased from use. According to this view, the Cyrillic script-seen as the keeper of Serb national identity-is under 'attack' from the Croatian language and the Latin script, together with Orthodoxy itself. This article administers a Critical Discourse Analytical perspective on contemporary Serbian linguistic nationalism, based on the texts produced by the core members of the linguist elite, so far not seen in scholarship, as most production tends to concentrate on the corpora of texts during the wars of the Yugoslav secession.

The political breakup of the Serbo-Croatian language along ethnic and religious lines has been studied in scholarship (Greenberg 2004, 2008; Bugarski 2009; Kordić 2010). Though the language was officially separated into fourCroatian, Bosnian, Montenegrin and Serbian-linguistically, these variants are still considered to be one language (Pohl 1996; Kordić 2001), commonly referred to as variants or versions of the polycentric Serbo-Croatian language (Kordic 2010). In order to foster the separation, nationally minded linguists have, since the nineties, been hyperproducing publications with the single goal of discursively creating four separate languages, and 'each publication of an instrument of codification has political, rather than linguistic, significance' (Greenberg 2004). In other words, 'the emergence of four successor languages to Serbo-Croatian since 1991 suggests that language birth in the Balkans came as a direct result of the explosive nationalist policies in Croatia, Bosnia-Herzegovina, Serbia, and Montenegro' (Greenberg 2004). Hobsbawm's famous utterance that 'languages multiply with states, not the other way around' (Hobsbawm 1990) is, in that light, particularly true when it comes to former Yugoslavia. We shall thus be debating one particular instance within the Serb variant of the language, which is the relation towards, and (mis)use of the Cyrillic script.

The nationalist Weltanschauung that has taken root in the countries comprising former Yugoslavia since the 1990s has divided former Yugoslav citizens into clear groups based on nationality/ethnicity, religion, and language. Thus, to be a Serb, a necessity was put in place that one should additionally and ineluctably be of the Orthodox faith, speak Serbian, and consequently use the Cyrillic script (similarly, for instance, a Croat would need to be Catholic, speak Croatian, and use the Latin script). The Cyrillic script, having been composed by the religious missionaries Cyrill and Methodius, has been used in language predecessors 
to Serbo-Croatian (or, nowadays, Serbian) in the region of the central Balkans for centuries, yet, as the centuries went by and the language developed, with the increase in literacy since the 19th century and the introduction of the Latin script, both Cyrillic and Latin have been used in what is linguistically the Serbo-Croatian language. Having in mind the common trait within nationalism worldwide to gaze into the past, the Cyrillic script has been pegged as 'intrinsically Serbian' (even though a large number of languages use it, from Bulgarian to Mongolian), a script that has been 'used for centuries'.

\section{Theoretical overview}

In 2004, Okey wrote how 'the identification of language and nationhood which has played so big a role in the history of the former Yugoslav peoples continues to exert its spell' (Okey 2004); the situation has not changed in the meantime, as

language continues to be a significant and constitutive aspect of nation formation. The communicative and symbolic functions of language provide means of achieving social cohesion and also of enabling political participation. Specifically, in both these functions language operates as a mode of national identification and exclusion (Haque 2015).

On a broader level, it is accepted in sociolinguistics that 'language played a central role in all 19th century national(ist) movements' (Wright 2011); it continues to do so today in former Yugoslavia, Serbia included, as language is an important element 'reaching to the imagination of a common descent and to ideas of an "innate nationality", (De Cillia et al. 1999). Consequently, the rhetoric of division, calling upon linguistic, national, ethnic and religious separation are continuing to blossom. As Blommaert and Verschueren wrote,

the ideal model of society is mono-lingual, mono-ethnic, mono-religious, mono-ideological. Nationalism, interpreted as the struggle to keep groups as 'pure' and homogeneous as possible, is considered to be a positive attitude within the dogma of homogeneism. Pluri-ethnic or pluri-lingual societies are seen as problem-prone, because they require forms of state organization that run counter to the 'natural' characteristics of groupings of people (Blommaert and Verschueren 1998).

All of the above is seen through theories of nationalism and appropriate sociolinguistic research. When it comes to questions of orthography, as Sebba wrote, it 'touches on matters of social identity, national identity, cultural politics, representation and voice' (Sebba 2007). In other words, orthography can become rather personal. In the case of nationalism, orthographic differentiation, i.e. creating the linguistic/orthographic Other will be of prime importance, as 'processes of identity formation... depend on defining the self as against some imagined "Other" (Irvine and Gal 2009). The abovementioned is in perfect accordance with theories of nationalism, where the forced differentiation between nations (sometimes referred 
to as 'Otherizing') is a crucial point in the very creation of the nation itself (see: Ignatieff 1995). Broader research on the subject has even found connection between language and race (not just nationality or ethnicity), such as the cases with some African languages (Irvine and Gal 2009), as well as a connection between orthography and ideology (Jaffe 1996).

Another instance that shall be of relevance for analysis is folk linguistics (Niedzielski and Preston 2000; Preston 2011; Albury 2014), that 'seeks to discover non-linguists' beliefs about language in general' (Preston 1994), as it will become clear during the course of the analysis that much of the rhetoric breaks linguistic norms more often than not, approaching the subject matter from a layman's, often emotional, perspective. This perspective allows the ideologue to 'connect' with the potential reader, connecting thus on an emotional level instead on a professional one. This naturally segues to the concept of language ideology, defined by Irvine as 'the cultural system of ideas about social and linguistic relationships, together with their loading of moral and political interests' (Irvine 1989), as we shall see in the analyzed corpus that a potent nationalist linguist ideology stands behind all of the discourse (Silverstein 1979; Kroskrity 2004). The establishing of the connection between the Cyrillic script as a 'key instance' with the newly formed Serbian language and the Serbian nation, as will be shown, is a part of the process of rhematization (or iconization), described by Irvine and Gal as 'a transformation of the sign relationship between linguistic features (or varieties) and the social images with which they are linked' (Irvine and Gal 2009), in this case, the Cyrillic script has been transformed into a symbol of nationhood.

When it comes to the general topic of linguonationalism in relation to SerboCroatian, academic research has been conducted and published, though not on contemporary Cyrillic-based Serbian nationalism. The perhaps most comprehensive work was written by Greenberg, covering Serbia, Croatia, Bosnia and Montenegro (Greenberg 2004, 2008); an extensive, detailed monograph about Croatian linguonationalism was written by Kordić (2010), including a number of research articles (Kordić 2009a, b), as well as reviews and critical articles (Kordić 1998, 2004). Jovanović published a smaller monograph on Serbian linguistic nationalism (Jovanović 2012), while Bugarski wrote several books about similar issues (Bugarski 2001, 2009). Nakazawa wrote a shorter research article on similar issues in Montenegro (Nakazawa 2015).

\section{Methodology and data}

We have chosen to approach the topic from the theoretical standpoint of Critical Discourse Analysis, with 'a focus on larger units than isolated words and sentences and, hence, new basic units of analysis: texts, discourses, conversations, speech acts, or communicative events' (Wodak and Meyer 2009), as 'rather than merely describe discourse structures, it tries to explain them in terms of properties of social interaction and especially social structure' (van Dijk 2015). The broad, all-encompassing nature of CDA is an excellent starting point for the analysis of discursively created identities, enemies and alleged problems. 
The corpus analyzed comes from the production of Serbian nationally oriented linguistics in the 21 st century; due to the constraints of a standardized research article, we have concentrated on the most relevant texts produced, such as those from the 2005 symposium, emphatically and hyperbolically named in the conference proceedings as 'Serbs are loosing their script. Lectures from the symposium The state of the script of the Serbian language today and how to save the Cyrillic script in the Serbian people and their language', published by the Society for the protection of the Cyrillic script-the Cyrillic script, the most active group of people who proliferate contemporary Serbian linguistic nationalism in the 21 st century. The symposium was attended by the most active and prolific among the Serbian nationalist linguist corps, including university professors; it was furthermore supported and funded by the state, making it a relevant source of primary data. It was described as 'a gathering of the greatest linguistic institutions and experts, representatives of culture and education, the academy of sciences, the Institute for the Serbian language, and other esteemed persons' (Lepojević 2005). Additionally, textual production from other nationally minded linguists that has been published on the same topic (such as in the form of articles in the daily Politika, that is known for allowing steadfast nationalist debate, or articles from the popular nationalist portal Nova srpska politička misao, adding to a total of eleven promulgators of a linguonationalist discourse).

We have identified six key instances in the discourse about the Cyrillic script that have been repeated profusely throughout the discourse, and several main topics that have been identified as most salient, as the analyses was approached with a back view to theories of nationalism, in which Otherizing, alleged defense of national markers and attacks against the 'enemies of the nation' are common. Said five topics are listed as follows:

(1) The idea that the Cyrillic script is 'under attack', 'disappearing', being 'erased'.

(2) The insistence on the Cyrillic script being the 'core' of the Serbian national identity within a running synecdoche; without the Cyrillic script, the Serbian nation would thus be weakened.

(3) The alleged/perceived 'perfection' of the Cyrillic script, often described as 'qualitatively' above other scripts, especially the Latin script.

(4) The discursive attack against the Latin script, Croatia and Croats, in which the Latin script is understood as intrinsically 'Croatian'.

(5) A strong perceived connection between the Cyrillic script and Serbian Orthodoxy, including the Serbian Orthodox Church.

These are implemented in the discourse by use of several strategies and topoi, the most prominent of which being the following:

(1) Assertive/declarative discourse, in which statements are given as facts that are supposed to be taken for granted; no explanation or corroboration of the given utterances is being given.

(2) Discursive 'otherization' and the topos of difference and threat, primarily in a binary opposition Serb/Croat, Orthodox/Catholic, Latin/Cyrillic. 
These five general themes were analyzed from a discourse analytical perspective, concentrating on the research questions: how and in what rhetorical manner is the Cyrillic script being presented as 'under attack', as a key instance in national identity, as connected to Orthodoxy, as 'perfect', as 'disappearing', as not being able to function properly if the Latin script is being used as well? What are the discursive strategies in which this is achieved?

\section{Assertivity in discourse: the 'vanishing' Cyrillic script}

According to Dragoljub Zbiljić of the Society, the question at hand is fairly clear and straightforward, as

the day-long debate of the greatest experts for this question (from the complete area of the Serbian language, as well as from across the borders) has shown unanimousness in the judgment of the experts for the Serbian language and script that the Cyrillic script has never been so endangered (Zbiljić 2005a, b).

Not being the only one, his opinions were supported by other members, one of them claiming that 'there is a fact that an inexplicable long-term inequality and almost complete discrimination of the Serbian Cyrillic script rules in Serbia' (Lepojević 2005). In short, 'experts' have been 'unanimous' in the 'fact', that is furthermore 'inexplicable', which is the 'discrimination' of the Cyrillic script, which is thus 'endangered'. A common thread in the rhetoric above is the assertive/declarative nature of the statements. The declarative discourse takes issues for granted, expecting the listener/reader to believe the speaker/writer. The following examples follow suite, where a row of synonyms and synonymic phrases denoting disappearance appears:

universities in Serbia almost do not use the Cyrillic script at all (Lepojević 2005)

the Serbian Cyrillic script is completely cast away (Lepojević 2005)

The Cyrillic script has almost been banished from public life (Milošević 2005)

The Cyrillic script is disappearing from the Serbian language more and more quickly. Especially from public use. Today, it has already been reduced to irrelevant percentages (Zbiljić 2005a, b)

As will be shown in the pages to come-thus, not only on the topic of the 'endangered' Cyrillic script-declaration lies in the core of the statements that use an array of lexical choices to support the claim that the Cyrillic alphabet is disappearing. Assertive discourse has, surprisingly, not been excessively studied. Most of the body of scholarly work concentrates on the declarative mood as a syntactic or semantic category, with pragmatics and rhetoric commonly held out of the picture. Yet, linguistic production so far still has relevant points to make on assertiveness, drawing on Speech-act Theory, "which tends uncritically to reproduce the norms of "assertive discourse" (Pratt 1986). According to Jary, 
the declarative has an 'assertoric force' (Jary 2011). Furthermore, as Cicourel has noted, connecting assertive discourse to folk linguistics, 'a central feature of folk models is their use of a taken-for-granted knowledge base or "personal" or "common sense" or "procedural" construction by individual actors' (Cicourel 1985), typical for declarative rhetoric. Some authors have concentrated on similar instances, such as common sense (Shutz 1945) or the personal (Polanyi 1958).

The assertive nature of the discourse was needed as the statements above are counter-factual, i.e. they do not correspond to reality; no proof was given that the Cyrillic script is 'dying away' because it is not; all official documents at the level of the state are written in it, it is used in daily life, the media, personal correspondence. Essentially, as Cicourel wrote, 'declarative systems of knowledge are viewed as advantageous because they are supposed to receive new knowledge without having to develop new rules of inference, yet these same rules make it possible to create new inferences' (Cicourel 1985), drawing on Rumelhart and Norman, who inferred that these rules are independent on facts (Rumelhart 1981), which in the case of the abovepresented rhetoric is true.

The declarative nature of the discourse is all-permeating, resulting in circular logic: 'The fact that the Society for the Protection of the Serbian Script has been founded tells about the state of the Cyrillic script and how much the state cares about' (Knežević 2005); further paradoxes being added by the fact that it is the state that sponsored the very event. It is important to notice that the declarative is 'unique among linguistic forms in allowing the speaker to present a proposition as relevant in its own right to the hearer' (Jary 2011); the declarative is, thus, 'in its own right in a context' (Jary 2011), since no context is being given to support the propositions. In other words, 'in assertive discourse the function of such statements is generally to emphasize that a fact is contrary to an expectation' (Wason 1965); in this case, contrary to reality.

Of all the speakers of the symposium, Lepojević was the most prolific one on the topic of the 'abandoning' the Cyrillic script:

The suppression of the Cyrillic script in the areas in which it has, together with its nation, been subject to hate and persecution, is not even mentioned (Lepojević 2005)

It is known that nobody from Serbia, no company, no institution, no expert or workers, have been able to use their own Cyrillic script or their own language...while others could spread and impose their script and language in Serbia without limits, and with the right that nobody could question! (Lepojević 2005)

everybody is throwing out the Cyrillic script (Lepojević 2005)

The Serbian Cyrillic script in Serbia is still ignored, suppressed, thrown away, disappearing (Lepojević 2005)

The evil is long and has been going on for a while, and the forces of evil are still at work (Lepojević 2005) 
The lexical choices used so far are 'suppression', 'throwing out', 'ignored', 'thrown away', 'disappearing', 'banished', 'cast away', 'being reduced', in an essentially polyptotonic, almost homiologic construction by use of synonyms in a wide semantic field, i.e. semantic repetition. Having in mind that the Cyrillic script is 'suppressed', and having in mind that it is taken for granted, the conclusion is that 'the Cyrillic script needs to be protected by institutional and individual effort' (Piper 2005).

Declarative, assertive rhetoric is needed as it 'signals that it is the expression of belief (a claim, a report) that the state of the world expressed by the propositional content is true' (Fraser 1996). According to George,

a certain kind of function is given to language in assertive discourse which is mined with difficulties: language is seen as representation and intentional, and therefore the position of the subject who signifies (judges, and affirms, and then goes on to legislate) remains unchallenged... the tactics of assertion bring into play an either/or logic essential to the production of the discourses of truth and falsity, which function as effects of power (George 1978)

Assertive discourse can, furthermore, represent both a 'real' or 'possible world' (Van den Broeck 1986); it is expected from the discourse recipient that the case is about the former. In essence, 'every assertive discourse contribution updates first the virtual content background' (Zaefferer 1991).

\section{The Cyrillic script as a marker of national identity}

In nationally grounded linguistic Weltanschauungen, 'language assumes the character of a clear identity marker' (Blommaert and Verschueren 1998) via the process of iconization. By use of an all-encompassing synecdoche, the rhetoric centers the Cyrillic script in the core, the heart of the language, almost identical with the language, inseparable, without which the 'Serbian language' cannot exist, a central node in the establishing of Serb national identity (Budding 1997).

linguistic science and professionalism yoked into a state program of de-Cyrillization, that is, de-Serbization (Vidić 2005)

the Cyrillic script... is one of the most important elements of the spiritual and cultural identity of the Serbian people (Matović, in: Trklja 2006)

This is a phonetic, and not etymological sound system, brought to perfection, second to none other. Being as such, it keeps and guarantees our ethnobeing and its integrity, holding its identity, it is a language that embodies our thought, and its language that materializes that thought, that is, represents it graphically (Kalezić, in: Trklja 2006)

If 'de-Cyrillization' is equated with 'de-Serbization', the Cyrillic alphabet is thus equated with the state of being a Serb, a central node of national identity. It furthermore 'guarantees' the same identity, as it is one of the 'more important 
elements' of it. As Garde noticed, the Cyrillic alphabet has an 'important symbolic value' (Garde 2004), as a 'minor but symbolically significant question' (Garde 2004). The alphabet of a particular language is often seen as an important issue within the pathos of the national identity, though mostly in the mid-twentieth century in the former USSR (Clement 1999; Fernández-Kelly and Konczal 2005; Alvarez Veinguer and Davis 2007; Hatcher 2008), as 'choosing alphabets can also be a way of reaffirming identity or signaling new associations' (Wright 2004), studied also by Fishman (Fishman 1988). Thus the alphabet was chosen to represent a linguistic/ethnic barrier, noticed as well by Voß, who wrote how "with the demise of Yugoslavia, attempts were made to strengthen these "soft ethnic barriers", which went hand in hand with an idealization of rural language traditions' (Voß 2011).

The rest of the discourse goes in the same vein, as Lepojević spoke of the following:

Our language has been called by an invented name for over fifty years; this is how it is called even today, even though all of our neighboring states that have resulted from the Serbian linguistic nation, have given this language that they speak and that they have been speaking for centuries, a new name, the name of their nation, and some of them are nations that have only now been created, while the Serbian people even today, the only one in this region, speaks a language that is still not called by its own name! (Lepojević 2005).

The emphasis on the 'Serbian linguistic nation' serves to further strengthen the importance of language and its elements-primarily the script-as a crucial instance within the pathos of national identity. It couples with the naming of the language, as it was important for the 'Serbian' language to have a different name from the 'Croatian', in a nominalist attempt to further decouple what is in linguistics still considered one language, Serbo-Croatian.

Nobody in Serbia respects that part of the Serbian people who use the Cyrillic script and who are sensitive to the discrimination of the Cyrillic script in their country, and who are of the rightful view that the Cyrillic script should be defended and kept as an extraordinary national value! One has to emphasize that this part of the people is surely larger in number, many times, than of those who belong to national minorities who live with us and respect the Cyrillic script! (Lepojević 2005).

Further emphasis in the lines above is given in the proclamation of the Cyrillic script as being an 'extraordinary national value', with an addition of the exclamation mark, as well as a stress on the will of the majority. The Cyrillic script, furthermore, serves to discursively, assertively claim that it makes the nation 'richer' than other nations in an 'age of the domination of the Latin alphabet':

The Cyrillic script is proof that, as a people, we are richer than much larger nations. Because in this age of the Internet, globalization and the domination of the Latin script via the English language, we have something that is only ours and understandable to us (Ristić, in: Trklja 2006) 


\section{Cyrillic 'perfection'}

Yet another instance that kept being repeated was the claim that the Cyrillic script was somehow 'perfect', 'better' than other alphabets. In some cases, the discourse takes the standard, assertive form: 'The Serbian Cyrillic script is a perfect script, it is the best among all Cyrillic scripts, the world has applauded it for years and taken it as an example'(Lepojević 2005), or that 'Serbs should understand that their civilizational obligation is to save their millennium-old perfect script' (Zbiljić 2005a, b).

In other cases, some attempts of justifying/corroborating the claim were made, as 'the Serbian Cyrillic script has its functional value as the script that in a very large measure corresponds to the Serbian phonological system' (Piper 2005). However, how exactly the Cyrillic script 'corresponds' to the Serbian phonological system is never elucidated, having in mind the linguistic reality that if a language has a written form, it has to correspond to the spoken form, lest it be entirely useless. Further attempts of explanatory discourse are given by Todorov and Todorov, who assert that the Cyrillic script is 'the most perfect script in the world' (Todorov and Todorov2005) because

precisely this way of writing is ergonometrically most favorable for man. It is especially favorable for the child who is still new to writing. In that way, the energo-informational use is at its best, with the least effort. The child's little hand is thus during writing strained only somewhat and tires the least.

(Todorov and Todorov 2005)

Yet another drift into folk linguistics, the passage above makes a poor attempt of justifying the claim of perfection by inciting sympathy for children, who would 'strain themselves' if they were to use the Latin script. Since this is an attempt of an introduction of a language policy (abandoning the Latin script and promoting the Cyrillic), we need to keep in mind that language policy is oftentimes 'an explicit topic of folk linguistics' (Albury 2014).

\section{The Latin alphabet and Croats/Croatian as the invading 'Other'}

The necessity of the discursive construction of the 'Other', especially in the context of the development of national identity, has seen its day in scholarship (Pan 2004; Wodak et al. 2009; Krzyżanowski 2010), as 'identity is constantly interactively constructed on a microlevel, where an individual's identity is claimed, contested and re-constructed in interaction and in relation to the other participants' (Norris 2007). The Other, in the Serbian case, was seen primarily in Croatia, Croats and the Croatian language (though the superseding Bosnian and Montenegrin played a part). A split thus had to be made, with Croats, Catholicism (to be debated in the pages to follow) and the Latin alphabet on one side, and Serbs, Orthodoxy and the Cyrillic alphabet on the other. As Greenberg wrote, 
after the Croatian Sabor (parliament) adopted a new constitution in December 1990 that included a section declaring Croatian to be the republic's official language, the Serbs responded by declaring Serbian to be the official language in the FRY in April 1992. Although Serbian and Croatian became technically distinct, much work still needed to be done in order to differentiate these two languages that had been more or less unified for almost 140 years (Greenberg 2008)

The 'much work' that needed to be done was, among other issues, the split between alphabets that occurred from the nineties onwards. Already in 1995, Radmilo 'Marojević regarded the Latin alphabet as alien to Serbian culture and argued that the Serbian government should disallow it' (Greenberg 2008), and this idea bore fruition as the decades went by, becoming one of the most prominent among the Serb national linguist corps. As Kloss has shown, it is often the task of the linguist to create a national standard in language (Kloss 1967), commonly one 'that promoted maximum comprehension and cohesion within the nation and maximum difference from others' (Wright 2011), and the use of the script was convenient. The 'maximum difference' was of crucial importance, as "elites needed to convince the mass of the people that they did indeed constitute a "nation". This could be demonstrated effectively if the group had a language which united them, and which, at the same time, differentiated them from their neighbors' (Wright 2011). In other words, 'the desire is to differentiate one's language from that of neighbors from whom one has separated. Serb, Croatian and Bosnian linguists have spent the last decades on Ausbau work' (Wright 2011), using the alphabets as a means to an end. This resulted in the presentation of the Latin script as intrinsically Croatian:

The Chinese have the most complicated script. What to say about the Arabs. The Greeks also do not use the Roman script. None of the abovementioned peoples had the idea to introduce the Croatian Latin script (Milošević 2005).

The Croatian Latin script has always come to Serbs under direct or, occasionally, somewhat hidden violence (Zbiljić 2005a, b)

the Serbian Cyrillic script is being increasingly neglected and suppressed by the Croat Latin script (Živković 2006)

The nominal phrase 'Croatian Latin script' needed to be emphasized by iteration, having in mind that the Latin script is being used in numerous languages throughout the world, that it came into existence long before the development of any Slavic nation and nationalism. The idea that 'Arabs and the Chinese' have the 'most complicated script' settles itself in the folk linguistic section, as it runs contrary to contemporary linguistics to present one alphabet as more 'complicated' than the other. By claiming there is 'violence', the very discourse is justified as a defense against the alleged violence. This is due to the idea that

Croats wisely understood that they need to (over)take the Serbian language (how else would they recruit Catholic Serbs to join the Croat national cor- 
pus?) without taking the script as well, as it is exactly the script (different from the Serbian one) that will serve them in realizing their linguistic theory about the autochthonous "Croatian language", in which today they arrived to the claim that Serbs have overtaken the Croatian language which Croats have been using before the Serbs for two hundred years!!! (Zbiljić 2005a, b).

As Ilić wrote, 'the narrative nucleus may be paraphrased as follows: "the Croats had no functional tradition/Then they came to idea to take over Serbian language", (Ilić 2014). Affect and stress is shown via three exclamation marks, a method that will be used more than once within the discourse. Other discursive instances are based on the lexical choice indicating attack ('bombarding', 'penetration') or force of nature ('flood'):

Our environment is simply bombarding us with the Roman script (Knežević 2005)

where does such a flood of the "Latin script" in Serbia come from? (Kleftakis 2012)

We are witnesses to a flood of the Roman script in the media, in education, in everyday communication (Knežević 2005)

The penetration of the Latin script into the Serbian language, as a non-Serbian script... have been enabled by the generosity of the Serbian ethnicum and historical circumstances (Ćupić 2005)

An interesting discursive moment is also seen: some of the creators of the discourse do not claim that the Latin script will overly influence Serbian national identity:

The rule of the Latin script over the Cyrillic often draws the conviction that by this process, the identity foundation of the Serbian people will be ruined. However, multiple examples, starting with the one from the Romanian language, show that the change of script does not fuel tectonic changes in identity by far (Janjić 2016)

This is a part of the larger picture of the geographical area, and a separate, yet connected, instance relating to Romanian linguistic, national and orthographic development, described by Safran:

Until the eighteenth century, Romanians used the Cyrillic alphabet in Church writings; and these are still seen on icons prominently displayed in Romanian museums. But with the growth of ethnonationalism, the Latin script began to be used by Romanians to differentiate themselves from the neighboring Slavs and to emphasize the 'Latinate' cultural heritage of their country (Safran 2008)

It seems, thus, that the language (and its script), together with national identity, are both fragile and strong at the same time, a discursive paradox noticed by the anthropologist Ivan Čolović, who wrote how 'parallel to the praise of the alleged 
granite strength of the language, the myth about the language and the national being in which it is nested talks about the strange sensitivity and the ability of the language to be spoiled as well' (Čolović 2008).

Other discursive instances draw our attention to folk linguistics and a layman's approach to linguistic issues yet again:

...to explain how much of a delusion it is that the Croat Roman script is understood by foreigners, and we are thus manifesting Europeanness. For example, foreigners say "fiš" for a fish (Fisch), and the word fish in the Roman script is understood only by Croats. The same goes for other words. Foreigners do not have ć, ž, č, š, đ, as well as some other letters. (Milošević 2005)

The running idea is a straw man fallacy by which perceived proponents of the Latin alphabet (commonly unnamed) base their insistence on it by stressing that it is 'understood by foreigners'. However, the passage in which 'foreigner say "fiš", and the idea that the German ('foreign') word 'Fisch' is 'understood only by Croats' presents a complete breakup with linguistics and an entry into folk linguistics and lay misconceptions. Furthermore, that 'foreigners do not have ć, ž, č, š, đ' is entirely counterfactual, having in mind that the graphemes quoted are used in languages from Czech to Sami, or, in the case that the author had in mind phonemes that are in Serbo-Croatian represented by the graphemes above, in thousands of languages. In Albury's words on folk linguists,

their inexpert status in linguistics, however, does not prevent them from drawing on their folk knowledge and beliefs about language to carry out, and even design language policy. They routinely decide how, when and where to use language and, in effect, solve language problems. These inexpert linguists are by default folk linguists of language policy (Albury 2014)

Other parts of the production claim 'scary' realities, 'discrimination' of the Cyrillic alphabet, now expanded via the introduction of the subjects of the 'attack' as Croats/Croatian:

what is scariest is that in Serbia, even after 1980, the spread of the Latin script was continued, even in the years after the second breaking of Yugoslavia and the separation of the parts that use the Latin script from the common state (Lepojević 2005)

We have not noticed a single, truly not even one, case of a legal reprimand for the discrimination of the Serbian Cyrillic script and the exclusive use of the Latin alphabet in public life (Lepojević 2005)

History tells us, however, that attempts of using an alphabet/script to further national goals and assimilation have been happening:

The so-called Altynsarin or Russian schools were first organized by the wellknown Kazakh enlightener Ibragim Altynsarin (1841-89), who introduced the Cyrillic alphabet adapted to the Kazakh language. This alphabet was compiled by the Russian orientalist and missionary N. Il' minsky, who was convinced 
that the Cyrillic alphabet would serve as the first step to the Russification of Kazakhs with a subsequent conversion to Christianity (Kendirbaeva 1999).

Nevertheless, they never succeeded. The attempt of a public scare by presenting an 'invading' Latin script perpetrated by the Otherized Croats was necessary, as

the nationalists' fear of linguistic diversity is logical. As soon as one subscribes to the ethno-linguistic doctrine, one believes that a group with its own language will want independence and to take part of the "ancestral territory" with it when it secedes. Worse still, it may want to regroup with an "alien" group across the border, increasing the power of "Them" and weakening "Us" (Wright 2011).

In order for the claims of an 'invading' Latin alphabet to be strengthened, another issue is the attack on the very fact that the language uses two scripts:

All linguists in their everyday written communication commonly connect their languages and their peoples to a single script each. It is not only the question of the lack of knowledge about language economy, but about the basic nature of language as well, that it has to neglect one script among the two. This is why the Serbian script is being neglected to make way for the Croatian alphabet, which has been protected for more than fifty years in various illegal ways (Zbiljić 2005)

From a linguistic perspective, this is yet another counterfactual stance, having in mind that Japanese, for instance, uses not two, but four scripts; hiragana, katakana, romaji and kanji. It is additionally used with the anti-Croat sentiment. In order to present the Cyrillic script as essential, it is also claimed that 'that the Serbian language has two alphabets is not primordial, it is barely eighty years old, that is, as old as the unification of Serbs, Croats and Slovenes in the second tenth of the 20th century' (Ćupić 2005), as blaming Yugoslavia is a relatively common trope of Serbian nationalism. Further stress is given by excessive use of exclamation marks yet again, as Zbiljić asks 'who else in today's Europe gets the idea that instead of thinking about the state, we are thinking about how many scripts we need for our (one) language!!!' (Zbiljić 2005a, b).

\section{Language and religion}

Scholars have noticed that there is a connection between national identity and language (Johnson 1996), as 'the nexus between religion and language is important enough not to be dismissed' (Safran 2008). In the Yugoslav case, 'in the course of the 19th century we thus see the convergence of two language communities which for centuries had been divided by religion and culture, a divide manifesting itself in the duality of the Latin and Cyrillic alphabets' (Voß 2011). As Safran wrote,

under Slobodan Milošević, the religious roots of Serbian ethnonational identity, manifested, inter alia, in the Eastern Orthodox monasteries in Kos- 
ovo, were emphasized and instrumentalized for political-territorial reasons, and language only incidentally. Croatians, for their part, demarcated their nation in religious terms, to some extent in reaction to the Serbian redefinition of the basis of their ethnonational identity (Safran 2008)

It is thus possible to say that 'the Croatian-Serbian linguistic distinction is a reflection of the distinction between Roman Catholics and Eastern Orthodox' (Safran 2008). For this reason, the discourse tends to draw upon questions of religion rather often, connecting/equating Orthodoxy with Serbia and the Cyrillic script.

The Cyrillic script is connected to Orthodoxy, so if Roman Catholic missionaries want to Catholicize the Serbs, they first of all need to separate them from the Cyrillic script (Milošević 2005)

The Glagolitic script is connected to the old, Pagan religion of the Slavs, the Cyrillic script to Orthodoxy, and the Latin script to Catholicism. The suppression of the Cyrillic script from Orthodox lands, thus, represents the missionary enterprise of the Roman Catholic Church by which, part by part, Orthodoxy is being destroyed, and a space for the acceptance of Catholicism being opened. (Milošević 2005)

The archetype of rounded edges which is connected to the rounded shape of Orthodox churches and monasteries-so, Orthodoxy-imperceptibly gives way to the archetype of sharp edges, which are connected to the sharp shapes of priories, Gothic style cathedrals, Catholic churches, that is, Catholicism (Todorov and Todorov 2005)

In the examples above, the connection between language and religion is openly and directly promoted, in a strict, repetitive and clear rhetorical division between Catholicism and Orthodoxy, thus, Serbs and Croat, Latin and Cyrillic scripts. Bennet has also noticed the connection between "alphabetic orthography and religious orthodox" (Bennett 2012). As Safran wrote, in such a Weltanschauung,

both language and religion are socially acquired, but early enough to provide the framework for the structuring of family relations, community cohesion, and ethnic identity. Moreover, they are often expressed in terms of each other. The medium is the message: Every speech community has its particular mind-set, which cannot be reproduced exactly in just any language (Safran 2008)

Similar instance in which Catholicism (equated with Croats), the perceived Orthodox-Cyrillic connection with a stress on national identity, including an 'unconscious Orthodox self', are seen throughout the discourse in an iterating, repetitive fashion, as repetition is seen by some theorist as a 'central linguistic meaning-making strategy' (Tannen 2007):

Research into the problem of the suppression of the Cyrillic script has lead us to the conclusion that it is, first of all, a missionary enterprise of the 
Roman Catholic Church, which is today additionally supported by the EuroAtlantic and globalist structures and centers of power (Milošević 2005)

For Nikolay, rescinding the Cyrillic script means rescinding half of Orthodoxy! (Milošević 2005)

firstly, one gives up on the Cyrillic script, adopting the Latin script as one's own personal script under the excuse that it is "easier to write", with the individual unconscious that by adopting the Latin form of letters within the Cyrillic script, a change in their own unconscious Orthodox self happens towards an indefinite mixture prepared first of all for giving up on Orthodoxy, then one's national identity, and an imperceptible shift to unitarism, or directly towards Catholicism (Todorov and Todorov 2005)

The Croat, i.e. the Catholic, or the user of the Latin alphabet, is the tangible Other that one needs to fight against. The 'conclusions' are given declaratively yet again ('research has led to the conclusion', yet no research has been shown), whilst the abandoning of the script is discursively equated with the abandoning of the very national identity. The rhetoric is somewhat old-fashioned, having in mind that "most of the aspirations for statehood in nineteenth-century Europe were in terms of ethnic nationalism based on language; and linguistic claims were often based on a legitimating connection with religion' (Safran 2008).

Being that the Cyrillic script, Serbian language and Orthodoxy exist in a state of interchangeability, further strength to the attempted argumentation is given by claims that the Church itself is under attack, by excessive use of lexical choice representing conflict and strife, weakening and oppression:

Beside the Serbian script and the Serbian language, the Serbian Church, that significant national marking and backbone, has been significantly weakened and suppressed by a many-year influence and labor...! Our national name has also been attacked most seriously, threatened by propaganda to declare itself as Yugoslavian (Lepojević 2005)

At one point, the discourse goes from folk linguistics to metaphysics, where linguistics is not even mentioned, and one of the author approaches the issue from an attempted theological standpoint, in a rather eldritch paragraph:

What are words for man, through which a certain thought is expressed and rounded up, for God the Creator are-sounds-letters. For every sound starts the energy (by calling) which comes into action and transfers its force by completing its task, either by concept or object. Thus, the words of Godsounds - are in complete harmony with effects. There is and there cannot be any difference between sound and action. Said—completed! (Mazić 2005).

Metaphysics and spirituality are the final retreat for such a discourse, as Predrag Piper of the Faculty of Philology in Belgrade claims,

in short, the situation is, regarded as a whole, bad, and the reason for it is the metaphysical evil that sets in motion various voracities of those who see spir- 
itual values and self-consciousness of other people first of all as a nuisance when trying to trick and rob a weaker people. (Piper 2005).

There is an 'actual implementation of a spiritual massacre over the Serbs' (Vidić 2005), further strengthening the metaphysical, the mystical. In summa, not unlike in Russia, where, after the Soviet era secularization, the de-secularization after the fall of Communism brought a renewed connection between the script and Orthodoxy (Bennett 2012), after the re-introduction of religion in Serbia in the nineties, a similar reclaiming of the Cyrillic script overtook significant portions of academic and public discourse.

\section{Conclusion}

As research has shown, 'linguistic strife is presented as an important force towards social disintegration' (Blommaert and Verschueren 1998), where 'language is only one identity marker among others. Descent, history, culture, religion, and language are treated as a feature cluster' (Blommaert and Verschueren 1998). In order to present language as a marker of identity, a row of discursive strategies which can oft be classified within the realm of folk linguistics have been created, where 'folk linguistic commentary can be seen as not just the phenomenon of an individual, but a window to programmatic systems of linguistic belief and understanding in a community' (Albury 2014), often connected with nationalist thought (Albury 2014). The Cyrillic script is presented as the locus of national identity, which is consecutively tied to Orthodoxy as an inseparable trinity of script, religion and nationality.

Throughout all the five major topics analyzed above, some clear common denominators were seen, which is the assertiveness of the discourse, combined with a folk linguistics approach that aims to connect on an emotional, instead of a professional level. As the social and linguistic reality of the Cyrillic script within Serbia-used on daily level, including all official state documentation and bureaucracy-ran contrary to the desired presentation of it as vanishing, assertivity was the key tactical choice for presenting the script as about to fade away. Next, presenting it as a crucial marker of national identity was conducted via the same declarative discourse, in lieu with known theories of nationalism, via rhematization (iconization). Its alleged 'perfection' - in addition to assertivity—saw more attempts of 'explaining', though via poor argumentation. The Cyrillic script, in addition to the vastly positive discourse about it, was however not the only topic, as the Latin script saw its demonization within the discourse, where, in a nationalist creation of the Other, it was presented as 'invading', as a representation of Croatia and Croats. The Cyrillic script was, finally, discursively and assertively connected to Orthodoxy, in a Catholic/Orthodox-Serb/ Croat binary.

What is problematic is that the nationalist folk linguist discourse is promulgated by some people who are in impactful, influential positions (such as university professors), whilst much of it is often published and publicized in well-read publications and portals, indicating a potential wide audience reach. As to the question of what kind of impact (or potential official linguistic policy) might arise due to it, it is 
difficult to make projections and predictions. Which type of nationalist symbol shall be used (primarily at the state official level) at which point is an issue that cannot be tackled within the scope of this article, but it is safe to say that with an already existing level of officialdom (such as the state sponsoring the symposium), it might get strengthened in the future. Whether a university professor or high school teacher might choose to approach these topics from such a standpoint has so far mostly been depended on the individual conducting the teaching, with instances of the nationalist viewpoint scattered throughout primers and monographs used for teaching purposes, yet this falls beyond the scope of this article and warrants special attention from a language policy perspective.

On a lighter note, counter-discourses have recently emerged, such as the Declaration of the Common Language (Deklaracija o zajedničkom jeziku, Ser-Cro.), signed by many prominent linguists, journalists and authors, in which a call upon recognizing the unity of the Serbo-Croatian language (at least linguistically)—however it might be locally named-has been made public. When it comes to the exact question of the Cyrillic script and its role as a national symbol, only a few critical articles have been published so far, all in online form.

The nationalist linguist discourse presented on the pages above is a continuation of the divisive discourse put forth by nationalist linguists and literary theorists during the breakup of Yugoslavia. Similar instances can be found in Croatian, Bosnian and Montenegrin nationalist linguistics, yet these are avenues for further research, especially having in mind that although the wars are over, discursive wars have continued. In the case of Serbia, assertive, nationalist folk linguistics has seen an increase in productivity, and as such, will be in need of further study.

Open Access This article is distributed under the terms of the Creative Commons Attribution 4.0 International License (http://creativecommons.org/licenses/by/4.0/), which permits unrestricted use, distribution, and reproduction in any medium, provided you give appropriate credit to the original author(s) and the source, provide a link to the Creative Commons license, and indicate if changes were made.

\section{References}

Albury, N. J. (2014). Introducing the folk linguistics of language policy. International Journal of Language Studies, 8(4), 85-106.

Alvarez Veinguer, A., \& Davis, H. H. (2007). Building a Tatar elite: Language and national schooling in Kazan. Ethnicities, 7(2), 186-207.

Bennett, B. P. (2012). Orthography and orthodoxy in Post-Soviet Russia. Orthography as Social Action: Scripts, Spelling, Identity, and Power.

Blommaert, J., \& Verschueren, J. (1998). The role of language in European nationalist ideologies. Language ideologies: Practice and theory, 2(3), 355-375.

Budding, A. H. (1997). Yugoslavs into Serbs: Serbian national identity, 1961-1971. Nationalities Papers, 25(3), 407-426.

Bugarski, R. (2001). Language, nationalism and war in Yugoslavia. International Journal of the Sociology of Language: $69-88$.

Bugarski, R. (2009). Nova lica jezika. XX Vek: Belgrade.

Cicourel, A. V. (1985). Text and discourse. Annual Review of Anthropology, 14(1), 159-185.

Clement, V. (1999). The politics of script reform in Soviet Turkmenistan: alphabet and national identity formation. Ohio: The Ohio State University. 
Čolović, I. (2008). Balkan-teror kulture. XX vek: Belgrade.

Ćupić, D. (2005). Ćirilica i mi. Srbi gube svoje pismo. Izglaganja sa simpozijuma "Današnji položaj pisma srpskog jezikai kako (sa)čuvati ćirilicu u srpskom narodu i njegovom jeziku". D. Zbiljić. Novi Sad, Udruženje za zaštitu srpskog jezika "Ćirilica", (pp. 11-12).

De Cillia, R., et al. (1999). The discursive construction of national identities. Discourse \& Society, 10(2), $149-173$.

Fernández-Kelly, P., \& Konczal, L. (2005). "Murdering the Alphabet" identity and entrepreneurship among second-generation Cubans, West Indians, and Central Americans. Ethnic and Racial Studies, 28(6), 1153-1181.

Fishman, J. (1988). The development and reform of writing systems. In U. Ammon, N. Dittmar \& M. Klaus (eds.), Sociolinguistics: An international handbook of the science of language and society (Vol. 2, pp. 1643-1650).

Fraser, B. (1996). Pragmatic markers. Pragmatics, 6, 167-190.

Garde, P. (2004). Unity and plurality in the Serbo-Croatian linguistic sphere. Language, Nation and State: Identity politics in a multilingual age (pp. 215-230). Berlin: Springer.

George, A. (1978). Introduction. In P. Foss \& M. Morris (Eds.), Language, sexuality and perversion (pp. 7-16). Darlington: Feral Publications.

Greenberg, R. D. (2004). Language and identity in the Balkans. Oxford: Oxford University Press.

Greenberg, R. D. (2008). Language politics in the Federal Republic of Yugoslavia: The crisis over the future of Serbian. Slavic Review, 59(3), 625-640.

Haque, E. (2015). Language and nationalism. The Routledge Handbook of Linguistic Anthropology. 317.

Hatcher, L. (2008). Script change in Azerbaijan: acts of identity. International Journal of the Sociology of Language, 2008(192), 105-116.

Hobsbawm, E. (1990). Nations and nationalism since 1780. Cambridge: CUP.

Ignatieff, M. (1995). Nationalism and the narcissism of minor differences. Queen's Quarterly, 102(1), 13.

Ilić, M. (2014). Collective narrative: the narrative on Croatian language from academic to far-right discourses in Serbia. Journal of Comparative Research in Anthropology and Sociology, 1, 49-73.

Irvine, J. T. (1989). When talk isn't cheap: Language and political economy. American Ethnologist, 16(2), 248-267.

Irvine, J. T. \& Gal, S. (2009). Language ideology and linguistic differentiation. Linguistic anthropology: A reader, (pp. 402-434).

Jaffe, A. (1996). The second annual Corsican spelling contest: Orthography and ideology. American Ethnologist, 23(4), 816-835.

Janjić, S. (2016). Дискурс онлајн медија у србији о угрожености ћирилице. Прилози проучавању језика, 46, 189-205.

Jary, M. (2011). Assertion, relevance and the declarative mood. Procedural Meaning: Problems and Perspectives, 25, 267.

Johnson, L. (1996). Central Europe: Enemies, neighbors, friends. Oxford: Oxford University Press.

Jovanović, S. (2012). Retrolingvistika. Istraživanje lingvističkog atavizma u Srbiji. Belgrade: Medijska knjižara Krug.

Kendirbaeva, G. (1999). 'We are children of Alash...'The Kazakh intelligentsia at the beginning of the 20th century in search of national identity and prospects of the cultural survival of the Kazakh people. Central Asian Survey, 18(1), 5-36.

Kleftakis, V. (2012) Zatiranje srpske ćirilice—plan ili slučaj? Nova srpska politička misao.

Kloss, H. (1967). Abstand languages and ausbau languages. Anthropological linguistics, (pp. 29-41).

Knežević, M. (2005). Narod, država, lingvistika i pismo. Srbi gube svoje pismo. Izglaganja sa simpozijuma. Današnji položaj pisma srpskog jezikai kako (sa)čuvati ćirilicu u srpskom narodu i njegovom jeziku”. D. Zbiljić. Novi Sad, Udruženje za zaštitu srpskog jezika "Ćirilica", (pp. 107-109).

Kordić, S. (1998). Diletantski napisana gramatika. U: Republika, 1(2).

Kordić, S. (2001). Naziv jezika iz znanosti gledan. Književna republika, 57, 1-2.

Kordić, S. (2004). Autism of Croatian philology (response to Ivo Pranjković). Književna republika, 2(7$8), 254-280$.

Kordić, S. (2009a). Plurizentrische Sprachen, Ausbausprachen, Abstandsprachen und die Serbokroatistik. Zeitschrift für Balkanologie, 45, 1-2.

Kordić, S. (2009b). Purismo e censura linguistica in Croazia oggi. Studi slavistici, 5(1), 281-297.

Kordić, S. (2010). Jezik i nacionalizam. Durieux: Zagreb.

Kroskrity, P. V. (2004). Language ideologies. A companion to linguistic anthropology, (pp. 496-517). 
Krzyżanowski, M. (2010). The discursive construction of European identities: A multi-level approach to discourse and identity in the transforming European Union, Peter Lang.

Lepojević, V. (2005). Izgubićemo sebe... Srbi gube svoje pismo. Izglaganja sa simpozijuma "Današnji položaj pisma srpskog jezikai kako (sa)čuvati ćirilicu u srpskom narodu i njegovom jeziku”. D. Zbiljić. Novi Sad, Ćirilica, (pp. 13-24).

Mazić, S. (2005). Božije reči u srbskom jeziku i slova u pismu ćirilici. Srbi gube svoje pismo. Izglaganja sa simpozijuma "Današnji položaj pisma srpskog jezikai kako (sa)čuvati ćirilicu u srpskom narodu i njegovom jeziku”. D. Zbiljić. Novi Sad, Udruženje za zaštitu srpskog jezika "Ćirilica”, (pp. 143-146).

Milošević, Z. (2005). Verski aspekti pitanja ćirilice danas. Srbi gube svoje pismo. Izglaganja sa simpozijuma "Današnji položaj pisma srpskog jezikai kako (sa)čuvati ćirilicu u srpskom narodu i njegovom jeziku”. D. Zbiljić. Novi Sad, Udruženje za zaštitu srpskog jezika “Ćirilica”, (pp. 71-78).

Nakazawa, T. (2015). The making of" Montenegrin language": Nationalism, language planning, and language ideology after the collapse of Yugoslavia (1992-2011). Südosteuropäische Hefte, 4(1), $127-141$.

Niedzielski, N. A. \& Preston, D. R. (2000). Folk linguistics, Walter de Gruyter.

Norris, S. (2007). The micropolitics of personal national and ethnicity identity. Discourse \& Society, 18(5), 653-674.

Okey, R. (2004). Serbian, Croatian, Bosnian? Language and nationality in the lands of former Yugoslavia. East European Quarterly, 38(4), 419-442.

Pan, C. (2004). The "China Threat" in American self-imagination: The discursive construction of other as power politics. Alternatives, 29(3), 305-331.

Piper, P. (2005). Simbolička vrednost srpske ćirilice i savremeno stanje srpske kulture. Srbi gube svoje pismo. Izglaganja sa simpozijuma "Današnji položaj pisma srpskog jezikai kako (sa)čuvati ćirilicu u srpskom narodu i njegovom jeziku”. D. Zbiljić. Novi Sad, Udruženje za zaštitu srpskog jezika "Ćirilica", (pp. 51-57).

Pohl, H.-D. (1996). Serbokroatisch-Rückblick und Ausblick. Wechselbeziehungen zwiischen slawischen Sprachen, Literaturen und Kulturen in Vergangenheit und Gegenwart. I. Ohneiser. Innsbruck (pp. 205-219).

Polanyi, M. (1958). Personal Knowledge. Chicago: University of Chicago.

Pratt, M. L. (1986). Ideology and speech-act theory. Poetics Today, 7(1), 59-72.

Preston, D. R. (1994). Content-oriented discourse analysis and folk linguistics. Language Sciences, 16(2), 285-331.

Preston, D. R. (2011). Methods in (applied) folk linguistics: Getting into the minds of the folk. AILA Review, 24(1), 15-39.

Rumelhart, D. E., et al. (1981). Analogical processes in learning. Cognitive skills and their acquisition, (pp. 335-359).

Safran, W. (2008). Language, ethnicity and religion: a complex and persistent linkage. Nations and Nationalism, 14(1), 171-190.

Sebba, M. (2007). Spelling and society: The culture and politics of orthography around the world. Cambridge: Cambridge University Press.

Shutz, A. (1945). On Multiple Realities. Philosophy and Phenomenological Research, 5, 533-575.

Silverstein, M. (1979). Language structure and linguistic ideology. The elements: A parasession on linguistic units and levels, (pp. 193-247).

Tannen, D. (2007). Talking voices: Repetition, dialogue, and imagery in conversational discourse. Cambridge: Cambridge University Press.

Todorov, B. \& Todorov, N. (2005). Primer autorskog prava kao jedne od mogućnosti zaštite, očuvanja i osavremenjavanja izvornog načina pisanja ćirilice. Srbi gube svoje pismo. Izglaganja sa simpozijuma "Današnji položaj pisma srpskog jezikai kako (sa)čuvati ćirilicu u srpskom narodu i njegovom jeziku”. D. Zbiljić. Novi Sad, Udruženje za zaštitu srpskog jezika "Ćirilica”, (pp. 113-117).

Trklja, N. (2006) a b v g d đe ž z i j k 1 lj m n nj o d u m i r a nj e ć i r i l i c e. Poliltika.

Van den Broeck, R. (1986). Contrastive discourse analysis as a tool for the interpretation of shifts in translated texts. Interlingual and intercultural communication: Discourse and cognition in translation and second language acquisition studies. Tübingen: Gunter Narr (pp. 37-47).

van Dijk, T. A. (2015). Critical discourse analysis. In D. Tannen, H. Hamilton, \& D. Schiffrin (Eds.), Handbook of discourse analysis (2nd ed.). Chichester: Wiley Blackwell. 
Vidić, N. (2005). Pismo je državno pitanje. Srbi gube svoje pismo. Izglaganja sa simpozijuma "Današnji položaj pisma srpskog jezikai kako (sa)čuvati ćirilicu u srpskom narodu i njegovom jeziku”. D. Zbiljić. Novi Sad, Udruženje za zaštitu srpskog jezika "Ćirilica”, (pp. 118-121).

Voß, C. (2011). Multilingual states and empires in the history of Europe: Yugoslavia. In B. Kortmann \& J. vad der Auwera (Eds.), The Languages and Linguistics of Europe (pp. 761-774). Berlin: De Gruyter Mouton.

Wason, P. C. (1965). The contexts of plausible denial. Journal of Verbal Learning and Verbal Behavior, 4(1), 7-11.

Wodak, R. \& Meyer, M. (2009). Critical discourse analysis: History, agenda, theory and methodology, na.

Wodak, R., et al. (2009). The discursive construction of national identity. Edinburgh: Edinburgh University Press.

Wright, S. (2004). Language policy and language planning. Pallgrave MacMillan: Basingstokes.

Wright, S. (2011). Language and Nation Building in Europe. In B. Kortmann \& J. van der Auwera (Eds.), The languages and linguistics of Europe (pp. 775-790). Berlin: De Gruyter Mouton.

Zaefferer, D. (1991). Conditionals and unconditionals: Cross-linguistic and logical aspects. Semantic universals and universal semantics, (pp. 210-236).

Zbiljić, D. (2005). Ćirilica i parapismo u srpskom jeziku. Srbi gube svoje pismo. Izglaganja sa simpozijuma "Današnji položaj pisma srpskog jezika i kako (sa)čuvati ćirilicu u srpskom narodu i njegovom jeziku”. D. Zbiljić. Novi Sad, Udruženje za zaštitu srpskog jezika “Ćirilica”, (pp. 65-70).

Zbiljić, D. (2005). Svedočenje o nestajanju ćirilice ili: srpski pravopisni skandal. Srbi gube svoje pismo. Izglaganja sa simpozijuma "Današnji položaj pisma srpskog jezikai kako (sa)čuvati ćirilicu u srpskom narodu i njegovom jeziku”. D. Zbiljić. Novi Sad, Udruženje za zaštitu srpskog jezika "Ćirilica", (pp. 6-7).

Živković, S. (2006). Za azbuku bez abecede. Belgrade: Politika.

Srđan Mladenov Jovanović is a Visiting Research Associate at Lund University in Sweden. He has conducted research and/or taught at several of European universities, such as the Palacky University Olomouc in the Czech Republic, the University of Bologna in Italy, the University of Košice in Slovakia, Istanbul Sehir Univesity in Turkey, as well as New Europe College in Romania. He is the author of a number of research articles and several books. His research deals mostly with Eastern European social, political, linguistic and historical issues from a discourse analytical perspective. 